\title{
УДК 575.17
}

ГОРПИНЧЕНКО М.Ю ${ }^{\otimes}$, АТРАМЕНТОВА Л.О.

Харківський наиіональний університет імені В.Н. Каразіна,

Україна, 61022, м. Харків, площа Свободи, 4

凶.gelios.8@gmail.com, (057) 707-55-71

\section{ХАРАКТЕРИСТИКИ ЧЕРНІГІВСЬКОЇ ПОПУЛЯЦІЇ ЗА ДАНИМИ ПРІЗВИЩ}

Mema. Було проаналізовано популяції Чернігівської області, а також здійснено порівняння їх 3 уже вивченими, щоб з'ясувати, як змінюється здатність прізвищ диференціювати популяції районного рівня в областях із різною географічною локалізацією. Методи. Використовуючи квазігенетичний маркер - прізвищ, - отримано генетичні показники популяцій Чернігівської області районного і обласного рівнів; проведено ïx порівняння 3 аналогічними показниками популяцій Полтавської (географічно центральної) й Одеської (географічно прикордонної) областей. Результати. Чернігівська область $є$ прикордонною, але базовий показник - індекс ізонімії в ній вищий $\left(I=4,57 \times 10^{-4}\right)$, ніж в прикордонній Одеській області, а також більший, ніж в центральній - Полтавській. Показник інбридингу в загальній чернігівській популяції становить $F_{s t}=11,43 \times 10^{-5}$. Показник ефективності міграції складає $v=17,37 \times 10^{-4}$ і займає проміжне місце між Полтавською й Одеською популяціями. Значення показника $H$ загалом для області складає 13,24 , показник надмірності розподілу прізвищ $R=34,67$. Висновки. Проведене дослідження доповнює картину генетичної своєрідності українських популяцій. Генетичні характеристики чернігівської популяції, iï відмінність від раніше вивчених центральної полтавської і прикордонної одеської пояснюються розташуванням Чернігівської області, особливостями ландшафту, етнічною і громадянською приналежністю населення, що географічно контактує. Ключові слова: квазігенетичні маркери, популяція, ізонімія, інбридинг, міграція.

Населення світу має складну ієрархічну популяційну структуру. В основі цієї ієрархії знаходяться елементарні популяції. Поділ цих популяцій в сучасному світі зазвичай іде за територіально-адміністративною

приналежностю. На процеси, що протікають у популяціях, впливають різні фактори, зокрема зовнішньо-популяційні (географічні) [1] та внутрішньо-популяційні (расові, національні, мовні, освітні, кастові, релігійні і т. д.) [2, 3] бар'єри, що розчленовують генофонди на відносно незалежні частини, що стійко відтворюються в низці поколінь. Особливістю структури популяцій сільського типу є відносно високий рівень інбридингу, в той час як в урбанізованих популяціях більше виражений аутбридинг $[1,4,5]$. Генетичні процеси змінюють структуру популяцій, впливаючи на пристосованість, яка проявляється на рівні здоров’я і працездатності ії членів. Сільські та урбанізовані популяції різняться пріоритетними генетичними процесами.

Структуру генофонду населення та процеси, які в ньому протікають, традиційно вивчають із використанням класичних i ДНКмаркерів. Ці маркери мають низку обмежень, що не дозволяють тотально аналізувати великі популяції. Цих обмежень позбавлені інші маркері, що у популяційній генетиці отримали назву «квазігенетичні». Найбільш привабливими серед квазігенетичних маркерів $\epsilon$ прізвища, оскільки у своїх найважливіших проявах - передача в поколіннях, поширення в популяціях вони нагадують гени. Використання прізвищ в якості квазігенетичних маркерів досліджували на індивідуальному і популяційному рівнях багато генетиків [1,3,6-20]. Взаємозв'язок між поведінкою генетичних маркерів крові і прізвищ було доведено дослідженнями [21]. У народів із патрилінійною традицією прізвища успадковуються, як і Y-хромосома, по батьківській лінії. Ця обставина робить зрозумілим інтерес учених до паралельного дослідження прізвищ і Ү-гаплогруп $[1,3,7,11-13,15,16,18]$.

Оцінки міжпопуляційної мінливості за генами і за прізвищами також виявляли великий збіг, що показано, зокрема, у ході вивчення структури генофонду багатьох народів $[8,10-$ $12,15,16,18]$. Суттєвий збіг демонстрували показники інбридингу, розраховані за даними біологічних маркерів і прізвищ в Австрії, Бельгії, Канаді, Данії, Естонії, Фінляндії, Франції, Німеччині, Ізраїлі, Італії, Сицилії, Японії, Голландії,

\footnotetext{
${ }^{\odot}$ ГОРПИНЧЕНКО М.Ю., АТРАМЕНТОВА Л.О.
} 
Норвегії, Росії, Іспанії, Швейцарії, США, Венесуелі, Китаї [7, 8, 10-19, 24].

У багатьох популяціях отримано високе значення коефіцієнта кореляції між показниками, розрахованими за частотами гаплогруп Yхромосоми, і частотами прізвищ. Прізвища широко використовуються в генетиці людини для аналізу розподілу популяцій, для оцінки коефіцієнта інбридингу, під час розрахунку $F$ статистик Райта. Масштабні дослідження з оцінки інбридингу і пов'язаного з ним тягаря спадкової патології були проведені для різних народів світу [1-19, 24].

Тривале існування українських прізвищ [22], їх невипадковий розподіл на території країни, що різняться історією, антропологічними типами населення і частотою генетичних маркерів [23], дають підставу розглядати їх в якості кандидатів на роль інструмента у популяційногенетичних дослідженнях.

Нашими попередніми дослідженнями 3 використанням прізвищ визначені загальні популяційно-генетичні характеристики українського населення, що розглянуті на рівні регіонів, областей, а також районів Одеської та Полтавської області. Тому метою нашого дослідження було проаналізувати популяції Чернігівської області, а також порівняти їх з уже вивченими, з'ясувавши, як змінюється здатність прізвищ диференціювати популяції районного рівня в областях із різною географічною локалізацією.

\section{Матеріали і методи}

Була використана база тотального списку прізвищ населення Чернігівської області. Область розташована на півночі України, на лівому березі Дніпра, у межах Поліської низовини та лісостепової зони Придніпровської низовини. Лісами вкрито $20 \%$ території області. В області протікає 1200 річок загальною довжиною близько 8,5 тис. км. Територія області становить 31

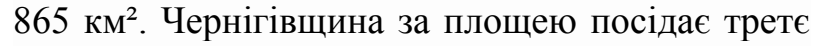
місце серед інших областей України. Область межує на заході з Київською, на півночі - з Гомельською областю Республіки Білорусь і 3 Брянською областю Російської Федерації, на сході - з Сумською, на півдні - 3 Полтавською областями України.
У дослідженні використано спосіб опису генетичної структури популяції, запропонований I. Barrai разом із співавторами [24]. Наявний матеріал проаналізовано із застосуванням методичних підходів, розроблених О.В. Балановською з колегами [1].

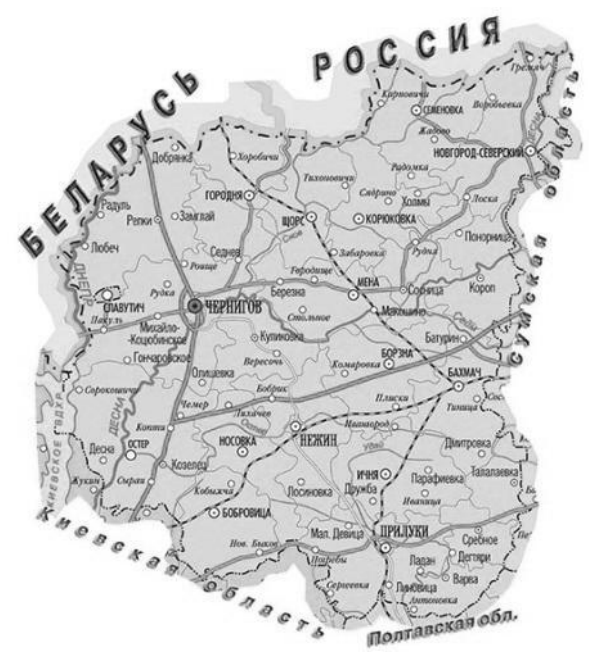

Рис. Чернігівська область (http://onlymaps.ru/news/chernigovskaya-oblast.html).

\section{Результати та обговорення}

Як було показано раніше на прикладі популяцій Одеської і Полтавської областей, різноманіття популяційно-генетичних показників залежить від географічного розташування області [25]. Зокрема, дисперсія розрахованих індексів має більш високе значення в Одеській області, ніж у Полтавській, що пояснюється різним географічним оточенням порівнюваних областей: полтавська популяція $\epsilon$ центральною, а одеська - прикордонною. Щодо головного показника - індексу ізонімії, то його значення вище у прикордонній одеській популяції, ніж у центральній - полтавській.

Чернігівська область $€$ прикордонною, але індекс ізонімії в ній вищий $\left(I=4,57 \times 10^{-4}\right)$, ніж у рикордонній Одеській області $\left(I=2,10 \times 10^{-4}\right)$, а також більший, ніж у центральній - Полтавській $\left(I=4,09 \times 10^{-4}\right)$. Тому за цим показником Чернігівська область, будучи прикордонною, тим не менше здається більш ізольованою, ніж навіть центральна - Полтавська. У ході аналізу популяцій районного рівня виявлено варіювання індексу ізонімії від $I=4,91 \times 10^{-4}$ у Чернігівському районі до $I=23,08 \times 10^{-4}$ у Срібнянському (табл.). 
Горпинченко М.Ю., Атраментова Л.О.

Таблиця. Генетичні характеристики популяцій Чернігівської області

\begin{tabular}{|c|c|c|c|c|c|c|c|}
\hline Популяції & $I \times 10^{-4}$ & $F_{S T^{\times}} \times 10^{-5}$ & $v \times 10^{-4}$ & $a \times 10^{2}$ & $\boldsymbol{H}$ & $\boldsymbol{R}$ & $\begin{array}{c}\text { Чисельність } \\
\text { населення }\end{array}$ \\
\hline Чернігівська область & 4,57 & 11,43 & 17,37 & 21,89 & 13,24 & 34,67 & 1257992 \\
\hline \multicolumn{8}{|c|}{ Райони } \\
\hline Бахмацький & 11,73 & 29,31 & 142,68 & 8,64 & 10,94 & 31,05 & 59703 \\
\hline Бобровицький & 10,64 & 26,59 & 222,39 & 9,61 & 10,88 & 29,21 & 42236 \\
\hline Борзнянський & 12,10 & 30,24 & 162,22 & 8,39 & 10,67 & 31,73 & 50899 \\
\hline Варвинський & 17,52 & 43,81 & 263,50 & 5,85 & 10,15 & 29,48 & 21618 \\
\hline Городнянський & 11,26 & 28,16 & 234,72 & 9,08 & 10,80 & 28,96 & 37787 \\
\hline Ічнянський & 12,71 & 31,76 & 178,56 & 8,00 & 10,69 & 30,72 & 44025 \\
\hline Козелецький & 11,39 & 28,46 & 142,19 & 8,90 & 10,95 & 31,16 & 61702 \\
\hline Коропський & 13,84 & 34,60 & 212,68 & 7,37 & 10,43 & 30,68 & 33930 \\
\hline Корюківський & 17,97 & 44,92 & 157,75 & 5,64 & 10,18 & 32,61 & 35216 \\
\hline Куликівський & 18,51 & 46,27 & 239,45 & 5,53 & 10,02 & 30,70 & 22523 \\
\hline Менський & 11,30 & 28,24 & 166,43 & 8,99 & 10,86 & 30,84 & 53132 \\
\hline Ніжинський & 8,45 & 21,13 & 98,01 & 11,94 & 11,54 & 31,65 & 120626 \\
\hline Новгород-Сіверський & 10,70 & 26,74 & 238,96 & 9,57 & 10,85 & 28,89 & 39084 \\
\hline Носівський & 13,15 & 32,88 & 185,69 & 7,74 & 10,60 & 30,79 & 40896 \\
\hline Прилуцький & 8,12 & 20,31 & 109,91 & 12,44 & 11,75 & 29,95 & 111918 \\
\hline Ріпкинський & 13,76 & 34,39 & 187,41 & 7,40 & 10,58 & 30,55 & 38733 \\
\hline Семенівський & 17,91 & 44,78 & 232,19 & 5,71 & 10,14 & 30,33 & 24005 \\
\hline Сновський & 16,76 & 41,91 & 184,04 & 6,07 & 10,38 & 30,71 & 32361 \\
\hline Сосницький & 18,28 & 45,71 & 182,00 & 5,56 & 10,04 & 32,52 & 30000 \\
\hline Срібнянський & 23,08 & 57,69 & 307,28 & 4,46 & 9,75 & 29,24 & 14071 \\
\hline Талалаївський & 19,32 & 48,30 & 297,84 & 5,32 & 9,97 & 29,19 & 17345 \\
\hline Чернігівський & 4,91 & 12,29 & 62,35 & 20,47 & 12,71 & 30,60 & 326182 \\
\hline
\end{tabular}

Примітки: $I$ - індекс ізонімії; $F_{S T}$ - індекс випадкового інбридингу; $v$-індекс міграції; $a$ - показник різноманітності прізвищ; $H$ - показник ентропії; $R$ - показник надмірності розподілу прізвищ.

Показник випадкового інбридингу є похідним від показника ізонімії. В модельній популяції з однаковими прізвищами коефіцієнт інбридингу теоретично є максимальним і дорівнює $F_{s t}=\frac{I_{r}}{4}=0,25$. Чим більше різноманіття прізвищ, тим нижчий показник інбридингу, який, як відомо, сполучений із частотою генетичних захворювань, в етіології яких присутня генетична компонента у вигляді рецесивних алелей схильності. Показник інбридингу в обласній чернігівській популяції становить $F_{s t}=11,43 \times 10^{-}$ 5 . Найвище його значення притаманне срібнянській районній популяції $\left(F_{s t}=57,69 \times 10^{-5}\right)$, найнижче - чернігівській районній $\left(F_{s t}=12,29 \times 10^{-5}\right)$.
Міграція - один з демографічних процесів сьогодення, який найбільш впливає на структуру популяцій людини. Чим більше мігранти генетично відрізняються від корінних жителів, чим більша їх питома вага, тим ефективніша міграція. Показник ефективності міграції, розрахований за формулою $v=\frac{1-I_{r}}{I_{r}(N-1)}$, для Чернігівської області склав $v=17,37 \times 10^{-4}$ і займає проміжне місце між полтавською $\left(v=15,77 \times 10^{-4}\right)$ i одеською $\left(v=20,71 \times 10^{-4}\right)$ популяціями. В районних чернігівських популяціях цей показник варіює від $v=62,35 \times 10^{-4}$ (Чернігівський район) до $v=307,28 \times 10^{-4}$ (Срібнянський район). 
Кількість прізвищ та їх частоту неможливо використовувати для порівняння популяцій різної чисельності. За однакових частотах прізвищ і їх різноманітності у популяціях різної чисельності буде формуватися різне число ізонімних (в нашому контексті - родинних) пар, що, як відомо, призводить до збільшення генетичного тягаря. Математично значення різноманітності відображається показником $\alpha$, в якому присутній показник різноманітності прізвищ через індекс міграції і чисельність популяції. Питома вага ізонімних пар дорівнює сумі квадратів частот прізвищ $\sum q_{i}^{2}$; чим більше зміщені частоти прізвищ від пропорції, тим вища ймовірність утворення ізонімної пари. Показник різноманітності прізвищ $a\left(\alpha=\frac{N v}{1-v}\right)$ в чернігівській обласній популяції дорівнює $21,89 \times 10^{2}$. Найвище його значення властиве популяції Чернігівського району $\left(a=20,47 \times 10^{2}\right)$, а найнижче - популяції Срібнянського району $\left(a=4,46 \times 10^{2}\right)$.

Значення показника ентропії $H$, як міри апріорної невизначеності, полягає в тому, що він залежить від різноманіття прізвищ окресленого населення. Якщо в групі $N$ особин $N$ прізвищ, то $H_{0}=\log _{2} N$. Якщо всі особини мають одне прізвище, $H=0$. Значення показника $H$ загалом для області складає 13,24 і незначно варіює по районах - від $H=9,75$ до $H=12,71$.
Показником ступеня відхилення розподілу частот прізвищ від рівної пропорції виступає показник надмірності розподілу прізвищ $R$ (розрахований за формулою $R=100\left(1-\frac{H}{H_{0}}\right)$, для обчислення якого розраховують показники $H$ (ентропія розподілу прізвищ, розрахована за формулою $\mathrm{H}=-\Sigma \mathrm{q}_{\mathrm{i}} \log _{2} \mathrm{q}_{\mathrm{i}}$ ). Для популяції Чернігівської області цей показник склав 34,67 ; максимальне значення в Корюківському $(R=32,61)$ та мінімальне в Новгород-Сіверському районі $(R=28,89)$.

\section{Висновки}

Проведене дослідження доповнює картину генетичної своєрідності українських популяцій. Генетичні характеристики чернігівської популяції, іiі відмінність від раніше вивчених центральної полтавської і прикордонної одеської пояснюються особливістю розташування Чернігівської області. 3 одного боку - це особливості ландшафту, а з іншого етнічна і громадянська приналежність народів, що географічно контактують.

Дослідження виконано за фінансової підтримки МОН Украйни, номер держреєстрації гранmy 0117 U 004836.

\section{Література}

1. Балановская Е.В., Балановский О.П. Русский генофонд на Русской равнине. М.: Луч, 2007. 416 c.

2. Cavalli-Sforza L.L., Bodmer W.F. The genetics of human populations. W.H. Freeman. San Francisco, 1971. 965 p.

3. King T.E., Ballereau S.J., Schurer K.E., Jobling M.A. Genetic signatures of coancestry within surnames. Curr biol. 2006. Vol. 21, № 16. P. 384-388.

4. Алтухов Ю.П. Концепция адаптивной нормы популяций и проблема аутбридинга. Вестн. АМН СССР. 1984. С. 16-21.

5. Курбатова О.Л., Победоносцева Е.Ю. Городские популяции: возможности генетической демографии (миграция, подразделенность, аутбридинг). Вавиловский журнал генетики и селекиии. 2006. Т. 10, № 1. С. 155-188.

6. Ревазов А.А., Парадеева Г.М., Русакова Г.И. Пригодность русских фамилий в качестве “квазигенетического” маркера. Генетика. 1986. № 22. С. 699-703.

7. Jobling M.A. In the name of the father: surnames and genetics. Trends Genet. 2001. Vol. 17, № 6. P. $353-357$.

8. Sykes B., Irven I. Surnames and the Y chromosome. Am. J. Hum. Genet. 2000. Vol. 66, № 4. P. 1417-1419.

9. Atramentova L.A., Ishchuk M.L., Utevskaya O.M. Genetic demographic analysis of Western Ukrainian populations: The marriage structure of populations from the Khmel'nitskii oblast with respect to ethnicity and birthplace. Russian Journal of Genetics. 2004. Vol. 40, № 8. P. 1131-1137. doi: 10.1023/B:RUGE.0000039727.82043.3f.

10. Scapoli C., Goebl H., Sobota S., Mamolini E., Rodriguez-Larralde A., Barrai I. Surnames and dialects in France: population structure and cultural evolution. J Theor Biol. 2005. Vol. 237, № 1. P. 75-86.

11. Immel U.D., Krawczak M., Udolph J., Richter A., Rodig H., Kleiber M., Klintschar M. Y-chromosomal STR haplotype analysis reveals surname associated strata in the East-German population. Eur. J. Hum. Genet. 2006. Vol. 14, № 5. P. 577-582.

12. McEvoy B., Bradley D.G. Y-chromosomes and the extent of patrilineal ancestry in Irish surnames. Hum. Genet. 2006. Vol. 119. № 1-2. P. 212-219.

13. Balanovska E.V., Romanov A.G., Balanovsky O.P. Namesakes or relatives? Approaches to investigating the relationship between y chromosome haplogroups and surnames. Molecular Biology. 2011. Vol. 45, № 3. P. 430-441. doi: $10.1134 / \mathrm{S} 0026893311030022$.

14. Sorokina I.N., Churnosov M.I., Balanovska E.V. The gene pool of the Belgorod oblast population I. Differentiation of all district populations based on anthroponymic data. Russian Journal of Genetics. 2007. Vol. 43, № 6. P. 697-704. doi: 10.1134/S1022795407060142. 
15. King T.E., Jobling M.A. Founders, drift, and infidelity: the relationship between Y chromosome diversity and patrilineal surnames. Mol. Biol. Evol. 2009. Vol. 26, № 5. P. 1093-1102.

16. Martinez-Cadenas C., Blanco-Verea A., Hernando B., Busby G., Brion M., Carracedo A., Salas A., Capelli C. The relationship between surname frequency and Y chromosome variation in Spain. Eur. J. Hum. Genet. 2016. Vol. 24, № 1. P. 120-128. doi: 10.1038/ejhg.2015.75.

17. Dipierri J., Rodríguez-Larralde A., Barrai I., López Camelo J., Gutiérrez Redomero E., Rodríguez A., Ramallo V., Bronberg R., Alfaro E. Random inbreeding, isonymy, and population isolates in Argentina. Journal of Community Genetics. 2014. Vol. 5, № 3. P. 241-248. doi: 10.1007/s12687-013-0181-x.

18. Solé-Morata N., Bertranpetit J., Comas D., Francesc C. Y-chromosome diversity in Catalan surname samples: insights into surname origin and frequency. Eur. J. Hum. Genet. 2015. Vol. 23, № 11. P. 1549-1557. doi: 10.1038/ejhg.2015.14.

19. Kandt J., Cheshire J., Longley P. Regional surnames and genetic structure in Great Britain. Transactions of the Institute of British Geographers. 2016. Vol. 41, № 4. P. 554-569. doi: 10.1111/tran.12131.

20. Monasterio L. Surnames and ancestry in Brazil. PLoS One. 2017. Vol. 12, № 5. e0176890. doi: 10.1371/journal.pone.0176890.

21. Горпинченко М.Ю., Буркова В.В., Утевская О.М., Атраментова Л.А. Украинские фамилии как квазигенетические маркёры. Ассоциация с группами крови и гаплогруппами Ү-хромосомы. Вісник Харківського національного університету імені В.Н. Каразіна. Серія: біологія. 2015. Вип. 25. С. 101-109.

22. Редько Ю.К. Сучасні українські прізвища. К., 1966. 216 с.

23. Утєвська О.М. Генофонд українців за різними системами генетичних маркерів: походження і місце на європейському генетичному просторі: дис. ... д-р біол. наук. К., 2017. 371 с.

24. Barrai I., Formica G., Scapoli C. et al. Microevolution in Ferrara: Isonymy 1890-1990. Ann. Human Biol. 1992. Vol. 19 , № 4. P. 371-385.

25. Горпинченко М.Ю., Атраментова Л.А. Популяційно-генетичні характеристики населення України, отримані з використанням прізвищ. Вісн. Київ. наи. ун-ту імені Тараса Шевченка. Біологія. 2015. Т. 1, № 69. С. 68-71.

\section{References}

1. Balanovska E.V., Balanovsky O.P. Russian Gene Pool on the Russian Plain. Luch. Moscow. 2007. 416 s.

2. Cavalli-Sforza L.L., Bodmer W.F. The genetics of human populations. W.H. Freeman. San Francisco. 1971. 965 p.

3. King T.E., Ballereau S.J., Schurer K.E., Jobling M.A. Genetic signatures of coancestry within surnames. Curr biol. 2006. Vol. 21, № 16. P. 384-388.

4. Altukhov Y.P. The concept of adaptive population norms and the problem of outbreeding. Vestn. AMS of the USSR. 1984. S. 16-21.

5. Kurbatova O.L., Pobedonostseva E.Yu. Urban populations: genetic demography approach (migration, subdivision, outbreeding). Vavilov journal of genetics and breeding. 2006. Vol. 10, № 1. P. 155-188.

6. Revazov A.A., Paradeeva G.M., Rusakova G.I. Suitability of Russian surnames as a "quasigenetic" marker. Russian Journal of Genetics. 1986. № 22. P. 699-703.

7. Jobling M.A. In the name of the father: surnames and genetics. Trends Genet. 2001. Vol. 17, № 6. P. 353-357.

8. Sykes B., Irven I. Surnames and the Y chromosome. Am. J. Hum. Genet. 2000. Vol. 66, № 4. P. 1417-1419.

9. Atramentova L.A., Ishchuk M.L., Utevskaya O.M. Genetic demographic analysis of Western Ukrainian populations: The marriage structure of populations from the Khmel'nitskii oblast with respect to ethnicity and birthplace. Russian Journal of Genetics. 2004. Vol. 40. № 8. P. 1131-1137. doi: 10.1023/B:RUGE.0000039727.82043.3f.

10. Scapoli C., Goebl H., Sobota S., Mamolini E., Rodriguez-Larralde A., Barrai I. Surnames and dialects in France: population structure and cultural evolution. J Theor Biol. 2005. Vol. 237. № 1. P. 75-86.

11. Immel U.D., Krawczak M., Udolph J., Richter A., Rodig H., Kleiber M., Klintschar M. Y-chromosomal STR haplotype analysis reveals surname associated strata in the East-German population. Eur. J. Hum. Genet. 2006. Vol. 14, № 5. P. $577-582$.

12. McEvoy B., Bradley D.G. Y-chromosomes and the extent of patrilineal ancestry in Irish surnames. Hum. Genet. 2006. Vol. 119, № 1-2. P. 212-219.

13. Balanovska E.V., Romanov A.G., Balanovsky O.P. Namesakes or relatives? Approaches to investigating the relationship between y chromosome haplogroups and surnames. Molecular Biology. 2011. Vol. 45, № 3. P. 430-441. doi: $10.1134 /$ S0026893311030022.

14. Sorokina I.N., Churnosov M.I., Balanovska E.V. The gene pool of the Belgorod oblast population I. Differentiation of all district populations based on anthroponymic data. Russian Journal of Genetics. 2007. Vol. 43, № 6. P. 697-704. doi: 10.1134/S1022795407060142.

15. King T.E., Jobling M.A. Founders, drift, and infidelity: the relationship between Y chromosome diversity and patrilineal surnames. Mol. Biol. Evol. 2009. Vol. 26, № 5. P. 1093-1102.

16. Martinez-Cadenas C., Blanco-Verea A., Hernando B., Busby G., Brion M., Carracedo A., Salas A., Capelli C. The relationship between surname frequency and Y chromosome variation in Spain. Eur. J. Hum. Genet. 2016. Vol. 24, № 1. P. 120-128. doi: 10.1038/ejhg.2015.75.

17. Dipierri J., Rodríguez-Larralde A., Barrai I., López Camelo J., Gutiérrez Redomero E., Rodríguez A., Ramallo V., Bronberg R., Alfaro E. Random inbreeding, isonymy, and population isolates in Argentina. Journal of Community Genetics. 2014. Vol. 5, № 3. P. 241-248. doi: 10.1007/s12687-013-0181-x.

18. Solé-Morata N., Bertranpetit J., Comas D., Francesc C. Y-chromosome diversity in Catalan surname samples: insights into surname origin and frequency. Eur. J. Hum. Genet. 2015. Vol. 23, № 11. P. 1549-1557. doi: 10.1038/ejhg.2015.14.

19. Kandt J., Cheshire J., Longley P. Regional surnames and genetic structure in Great Britain. Transactions of the Institute of British Geographers. 2016. Vol. 41, № 4. P. 554-569. doi: 10.1111/tran.12131. 
20. Monasterio L. Surnames and ancestry in Brazil. PLoS One. 2017. Vol. 12, № 5. e0176890. doi: 10.1371/journal.pone.0176890.

21. Gorpynchenko M.Yu., Burkova V.V., Utevska O.M., Atramentova L.A. Ukrainian surnames as quasi-genetic marker. The correlation with blood group and Y-chromosome haplogroups. The Journal of V.N. Karazin Kharkiv National University. Series "Biology". 2015. Vol. 25. P. 101-109.

22. Red'ko Yu.K. Modern Ukrainian surnames. Kyi'v: Naukova dumka, 1966. $216 \mathrm{~s}$.

23. Utevska O.M. The gene pool of Ukrainians revealed by different systems of genetic markers: the origin and statement in Europe. K., 2017. $371 \mathrm{~s}$.

24. Barrai I., Formica G., Scapoli C. et al. Microevolution in Ferrara: Isonymy 1890-1990. Ann. Human Biol. 1992. Vol. 19 , № 4. P. 371-385.

25. Gorpynchenko M.Yu., Atramentova L.A. Population genetic characteristics of the population of ukraine obtained with the use of surnames. Bulletin of the Kiev National Taras Shevchenko University. Biology. 2015. Vol. 1, № 69. P. 68-71.

\section{GORPYNCHENKO M.Yu., ATRAMENTOVA L.A.}

V.N. Karazin Kharkiv National University,

Ukraine, 61022, Kharkov, Svobodysq., 4, e-mail:8.gelios.8@gmail.com

\section{CHARACTERISTICS OF CHERNIGOV'S POPULATION BY THE PRESENTATION DATA}

Aim. The population of the world has a complex hierarchical population structure. At the heart of this hierarchy are elementary populations. Methods. Using the quasigenetic marker - surnames - the genetic indices of the population of the Chernihiv region of the rayon and oblast levels were obtained, comparing them with similar indices of the populations of the Poltava (central) and Odessa (borderline) populations. Results. The Chernihiv region is borderline, but the base indicator is an index of isonomy higher $(\mathrm{I}=4.57 \times 10-4)$ than in the border region of Odessa, and also more than in the central - Poltava population. The index of inbreeding in the Chernihiv population is Fst $=11.43 \times 10-5$. The indicator of migration efficiency was $\mathrm{v}=17.37 \times 10-4$ and occupies an intermediate position between the Poltava and Odessa populations. The value of the index $\mathrm{H}$ as a whole for the region is 13.24 , the index of redundancy of the distribution of names is $\mathrm{R}=34.67$. Conclusions. The study complements the picture of genetic peculiarity of Ukrainian populations. The genetic characteristics of the Chernihiv population, its difference from the previously studied central Poltava and border area of Odessa, are explained by the peculiarity of the location of the Chernihiv region, the features of the landscape, the other ethnic and civic belonging of the geographically contacting peoples.

Keywords: quasigenetic markers, population, isonymy, inbreeding, migration. 